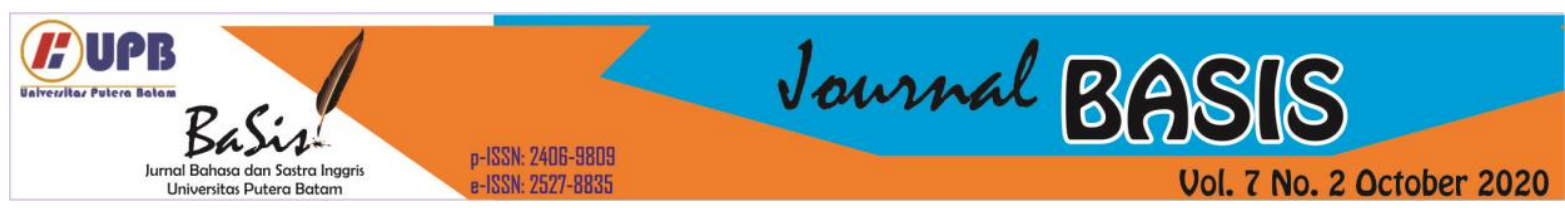

\title{
WOMEN'S LANGUAGE OF MEXICAN FEMALE CHARACTERS DEPICTED IN TELENOVELAS: AN AMERICAN STUDIES
}

\author{
Nurvita Wijayanti ${ }^{1}$ \\ Universitas Bangka Belitung, Bangka, Indonesia \\ wijayavita88@gmail.com ${ }^{1}$ \\ M.Afifulloh ${ }^{2}$ \\ Universitas Gadjah Mada, Jogjakarta, Indonesia \\ apiepm@gmail.com ${ }^{2}$ \\ Andri Fernanda ${ }^{3}$ \\ Universitas Bangka Belitung, Bangka, Indonesia \\ andrifernanda92@yahoo.com ${ }^{3}$
}

\begin{abstract}
The issue about gender equality seemed in its glory in all over the world. Women might enjoy the equality and even they had a chance to promote themselves to become the future woman leaders. Not even Mexican-American women who got the impacts of the movement of gender equality. However their telenovela show told the opposite. This study aimed to examine the female characters of telenovela through the language choices. This research wanted to prove that by having telenovela as the soap opera, Mexico had their female characters to be the subaltern which showed the inferiority toward male characters. The objects of the research were two newest telenovelas aired during 20152019: Vis a Vis (Locked Up) and Tiempos De Guerra (Morocco: Loves in Times of War). Descriptive qualitative method was used to comprehensively analyze the language choices by female characters in those three telenovelas. The study showed that although Mexican telenovela had improved their female characters to be the stronger ones, their language choices still depicted their inferiority toward male characters.
\end{abstract}

Keywords: American Studies, Language and Gender, Telenovela, Women's Language

\section{INTRODUCTION}

In 1990s, telenovelas, originally from Mexico, were very popular among variety of ages. Old women and men, middle-age women and men, boy and girl teenagers, even children knew what the titles of telenovela were, one of them was Marimar. It was a drama that had many viewers all over the worlds, including Indonesia, the researchers' origin as it is the media to construct identities of a certain community that has the same experience like immigrating community
(Morales\&Simelio: 2016). Marimar brought the theme about unconditional love depicted from a very poor girl who fell in love with a very rich man. It shows the marginal system of real-life struggle domestic workers in Mexico (Rios, 2015). another research concluding that there is a subordinate gender is shown that Mantras women who get marginalized (Krismanti, 2020). It turned out that later on Marimar as the name of female protagonist had to face many miserable obstacles in order to keep her love to 
the rich man. On the other hands, this rich man had no significant struggle to fight back to get his woman back into his arm.

Telenovelas aired by media become one of the influence for society especially who has the same values and class level. Media gives a room to specific community to feel the same way therefore they can relate it with their own life. As a result, they get attached with the melodrama.

Media becomes one of the tools to access the interpretation relating to the imitation of reality; one of them is about the definition of femininity. It is the conformity of gender relations as they exploit the female body to sell products, define beauty, and elegance standards and disseminate ideas and moral respectability in terms of sexuality and family care (Ronsini, 2016). The female bodies are sold to represent the reality in society that might say males are more interested to see female's bodies to advertise the products. In addition, males also require females should have standards so that they can be satisfied by the outer appearances of female.

The requirement that should be fulfilled by the women might have relation toward the way women use verbal expression; one of them is shown in the language that is used. Therefore, language has significant role to find out the specialty of women. The language used by the female characters include the gesture and body language.

Sociolinguistics study is used to elaborate how the women's language influence the gender's characteristics toward each other. In this study, there are two elements which are women's and men's languages. Meanwhile, American studies are used to examine the study about Mexico which is part of The US.
The researchers discuss these three telenovelas. They are Vis a Vis (Locked $U$ p) talks about a young naïve woman who falls in love with her boss (IMDb, 2015), and it arouse the researchers hypothesis that the woman might have inferiority toward male characters. The second series, Tiempos De Guerra (Morocco: Loves in Times of War), tells about a group of trainee nurses from Madrid's upper class being sent to open the hospital in the city of Melilla to help Spanish soldiers who have injured in the battle (IMDb, 2017). Since it has historical background, the researchers have a hypothesis that these women also have subaltern position.

These two series were made in 2000 s that means they must be different concept of the 1990s' telenovelas. It means that it has progressed since the feminist movement emerged stronger than before. Therefore, the researchers had decided to focus on the female characters and their choices of language that might be different with male language choice.

Moreover, this research offers two main research questions which are what women's languages are depicted in these three telenovelas: Vis a Vis (Locked Up) and Tiempos De Guerra (Morocco: Loves in Times of War) and how those languages represent the gender inequality. These two research questions are examined through the theory of women's and men's language, theory of gender equality and the theory of American Studies.

\section{LITERATURE REVIEW}

There are many researches talking about gender inequality in Mexico through the socio-cultural perspectives. One of them is the study from Martinez that the definition of gender equality is from the origins being traced to social 
structures that perpetuate men's domination of women in all areas of private and public life what is so called as patriarchy system (Martinez, 2014). Mexico has exposed the gender inequality since $1990 \mathrm{~s}$ in the representation of the soap operas called telenovelas. In those telenovelas, the main characters which are mostly women became the subalterns. They were dominated by men.

Furthermore, in her other journals, Martinez says that Mexico has many complex problems relating to gender inequality such as suicide, fertility, abortion, partner violence, poverty, educational attainment and industrialization (Martinez, 2007). It means that Mexican women mostly suffer from those kind of field. All of those characteristics are exposed in the telenovela showing that women always become the subaltern. Women are always described as poor and weak characters.

A journal titled "Representation and Disjunction: Made-up Maids in Mexican Telenovelas" shows the perspective of social culture. It states that the most common plot devices in telenovela is about a domestic worker or maid telling about poor, beautiful maids. Furthermore, it makes the audiences look at the sector's experience (Rios, 2015). this journal states about the stereotyping of maids in Mexico that has gender issue in it that makes the spectators see it is fine to have the plot like the telenovelas offer. It is appropriate to watch that women should always be in a domestic area, especially to be exposed as a beautiful maid.

The development of telenovelas happens in the extension of it not only in Mexico but in Nigeria through the perspective of LGBTQ emergence. The
"Taste of Love" offers the heterosexual romance and its complicated problem of supperich rivals. It does not only include Mexican but Nigerian telenovelas that has the similar themes such as centralized sex, scandal, and multibillion-dollars deals (Tsika, 2019). Today's telenovelas indeed has improved by the themes as it is seen in this journa. It is part of LGBTQ movement. However, still the basic theme to be exposed is about subalterns.

The study of sociolinguistics shows that there are women's and men's language. Women's language stereotypes that women have restricted vocabulary than men, women use more adjectives than men, women mostly do not finish their sentences, and women have more superficial words (Lakoff, 1975). In addition, Coates proves that:

"It is apparent that when friends talk to each other in single-sex groups, one of the things that is being 'done' is gender. In other words, the fact that female speakers mirror each other's contributions to talk, collaborate in the co-narration of stories and in general use language for mutual support needs to be considered in terms of the construction of femininity. For many men, by contrast, connection with others is accomplished in part through playful antagonisms, and this ties in with men's need to position themselves in relation to dominant models of masculinity."

Coates differentiates the way the women and men have claimed their language. She summarize them by the way the women talk to each other. Mostly they show some support in the way they contribute the topics of conversation. It is the opposite of the men's side. It states that when a man offers a topic, it does not mean the support to other topics offered by other 
men, but it is a satire talking that leads to men's pride what is so called as masculinity.

Gender study and its relation to American studies are two things that will support the system of language and gender. In sociolinguistics and other social sciences, gender refers to sexual identity in relation to culture and society (Nordquis, 2019). Therefore, language has become a significant aspect to prove that women and men are different even though the gender issue is included especially what has happened in Mexico as one of the states in the US.

\section{RESEARCH METHOD}

This study uses a qualitative research that requires the researchers to understand the issue of the upbringing topic such as behavior, motivation, actions, and others. In this pace, the researchers use the symptoms that occur and describe the issue being discussed (Idrus, 2009). It means that this is part of the literature study examining the object through the behavior of the female characters in Vis a Vis (Locked Up) and Tiempos De Guerra (Morocco: Loves in Times of War). Furthermore, the motivation and actions done by those female characters were analyzed through their language choices.

There were several steps done to find the valid data of this research. The first step was re-watching the series randomly. The second was reanalyzing those two series by considering that those series were made in 2000 s that means they must be different concept of the 1990s' telenovelas. The next step is the researchers chose the best approach and theories which is American Study and Sociolinguistics.

Sandelowski says that qualitative descriptive method is somehow different from other types of qualitative research, such as grounded theory, ethnography, phenomenology, or narrative analysis - essentially descriptive rather than interpretive in focus (Sandelowski, 2010). It does not mean that the researchers purely doing description but they also do the interpretive in different ways. This method allows the researchers to reading of lines. In other words, to find the data, the researchers focus on the lines spoken by the female characters of those two series of telenovela. Those lines were sorted out to match the approach and theory.

\section{RESULT AND DISCUSSION}

According to Coates' theory, there are several types of language structures owned by women comparing to men. She further makes division in terms of vocabulary, swearing and taboo words, grammar, literacy, pronunciation and verbosity.

Johnson states that the words flirtation and frightful as 'female cant'. It means that women have contributed limited vocabulary than men therefore they only stereotype as doing flirting and being frighten. It shows in below script:

Mum? ...... - Simon, the guy I mentioned ...- But this plan came up overnight,just like that? - Yes, I had some free time, so I said "Let's go" (Vis a Vis s01 e01, 2015).

This conversation happens when Macarena, the female character, is called by her Mum but it turns out that she rejects her Mum's invitation to have dinner at home. She has another appointment with her boyfriend. It seems that she has said yes easily without thinking the first appointment. Her flirtation is shown in the way she 
says that she has free time and easily saying 'let's go' to her boyfriend. She feels afraid that her boyfriend might leave her instead she gives up her family dinner appointment.

The other proves is in the other dramas. It shows below:

- Is something wrong, Julia? I've been thinking about it.

- I don't think I should keep helping yоu.

- I'm scared that I'll kiss you the next time. How are you feeling today, Ahmed. (Tiempos De Guerra, s01e08, 2017).

This drama shows historical background telling about a group of nurses being sent to Morocco to have a mission in a war. This situation states that a female nurse tries to flirt with her patient, an Arabic called Ahmed. They way she flirts might have any significant to keep Ahmed alive and stay conscious. However, it seems that it is part of the woman's job at that time for the sake of the men's safety.

Swearing and taboo language are what women will avoid in speaking, at least it is what researchers find in those three dramas. Yes, some of the women do some swearing and taboo words, however the output can be so different compared to what happen to men's swearing and taboo words.

- Damn, Valbuena. - Valbuena

Fuck! - What happened?....That guy's an arsehole. (Vis a Vis s01 e01, 2015).

In this scene, a group of women in jail talks about the unfair issue. The female characters named Macarena shouts out a swearing. Further explanation says that fuck has related to men's history when they only do obscene expression when having sex with their women. Therefore, it has different impact when women follow what men have said earlier toward them.

Talking about swearing words have been spoken by the female characters in the historical drama.

-Didn't you get my letter? - a letter for me? No

- You have to tell him.

- I know. I know but it was easier by letter.

- You've realized that he's a crook?

- Why do you care? I don't want to drive you into a scumbag like him. (Tiempos De Guerra, s01e08, 2017).

This conversation happens between two female nurses reminding each other not to easily get fell with a man. One of the nurse mention about scumbag as a part of the taboo word. This setting of the drama is actually historical background it means that at this modern time, the director does not change the social setting. They still make it as natural as it is. Once again, women are part of the subaltern if they keep filming it using historical background without any changing era.

Grammar also has significant differentiation toward men's and women's language. The use of he and they requires a sex-indifinite pronoun. The important point is that the male domination pronoun has been replaced by neutral dominant pronounce such as they not he only.

- The first day here? You don't think you'll be here for such a long time. When you arrive here, they get you in....- They undress you, they touch yo. It's like being raped. (Vis a Vis s01 e01, 2015). 
The situation tells about Macarena's first day in jail and her roommates warn her about the prison keeper that is actually a man, the one and only supervisor in that jail. He will do something sensual to the woman prisoners. However in this case, the women mention they rather than only $h e$. it shows that women feel secure if they can share the same thing happened to them and they want to emphasize that there are lots of doers so the hearers must be afraid, just like them whom get jailed earlier.

Women had lack access to literacy than men not until the twentieth century. Before that period, only women of the middle class and above were likely to literate, further it is literate in vernacular. Therefore it leads to underestimating women when they talk about particular serious issue. Men tend to reject the idea from the women.

- Those bitches got into the cell, and they searched and searched, turning everything upside down. - Do you mean a prisoner killed her to get the information? That's what I like you to understand, Governor Aguirre. (Vis a Vis $\quad$ s01 e01, 2015).

It shows the Governor gives unbelievable expression to the woman's explanation that he thinks it does not make sense. He thinks it is part of the lack of reading literacy and not having many references outside. He thinks that this woman, Macarena, is a narrowminded woman. This drama is a modern drama that has LGBTQ theme and it has already opened to publication. However, it seems that although it has lesbian topic in it, the women's position is still worried.

In the term of pronunciation, it can be said that Mexican women have their own accents and dialects that show whether they are the educated women or men, having important position in the society, and if they are outsiders. The characters who all Mexican women and men cannot be stated to have pronunciation since they have the same standard accents and dialects.

On the other hands, verbosity which is part of language happens in women's and men's language. The cultural myth shows that women talk too much. The other side to women's verbosity is the image of the silent woman. This is part of the movement telling that the improved pride of a woman is shown that being silent is golden. However, these three dramas tell the oposite. All of female characters are shown talkative.

- Yes, thank you.

- I'm heterosexual.

- We're all heterosexual here. It's okay. There's no need to answer now. You can let me know in another day. Ok, cool.

- Teresita. They just asked me why are you being nice. About my sex life. Just relax don't be dirty. Affection rises between women. You miss a hug, a kiss Everything. They want affection. That's all. (Vis a Vis s01 e01, 2015).

It is proved why the other women show the intimidation toward another woman, they do it while they keep talking too much.

The second drama which talks about historical background also shows that women in the past talking too much. This story is not changed to adjust the modern time today.

- Scalpel, Scalpel, please, Sir, he has no pulse.

- His parents will be coming to Mellila to get him. 
- How was he evacuated, sir? On a packhorse to a position where the ambulance could get to him. That is what killed him. The same all of those not attended to in proper conditions. (Tiempos De

Guerra, s01e08, 2017).

The context shows that the female nurse is described as a talkative and annoying speaker talking and asking rather than understand the situation to take care of the patient. It is unfair to watch that somehow a man can also be talkative when he is nervous or in the panic situation. In this drama, the colonel just takes it cool.

From all evidence stated in the drama, it shows that actually the previous study is relevant. It depicts the Mexican female characters who stereotype to become a subaltern. This research provides the new support which is from the perspective of women's language. The theory being used is adjusted to the modern time however it seems to have a weakness to prove that there are no progress in language when talking about feminist movement.

Feminist movement surely thinks about the use of language in the future spoken by women in general. It might be unfortunate to find out that it has no significant progress. In this case, it is proved in the Mexican telenovelas. At first they talk about unrealistic female characters who were always oppressed by the society, struggling alone, and falling in love with superrich man. In this modern era, though the themes can be various and following the newest issue, it still relates to the past era.

Mexico is a country in the southern portion of North America which means that there is a discrimination about the race and skin color. Regarding to becoming the third largest trading partners of the US, they still receive a discrimination. It means that Mexico has two repressed position in the society and media as the imitation of the society. While America has improved the gender equality issue, Mexico remains the same.

\section{CONCLUSION}

The improve of gender equality can be seen through the language. This language shows the changing era has been through. The language describe how women try to be equal with man, not by following men's standard language but by having their own standard to reveal the same meaning as the previous men's language has depicted.

The tools to differentiate men's and women's languages in this nowaday's gender issue has been formulated. There are six (6) elements of formulating the women's language that is different with men's language: vocabulary, swearing and taboo words, grammar, literacy, pronunciation and verbosity. Those elements have already been adjusted to the gender issue to embrace gender equality noting that in language areas, men and women are still different but not in the tracing of masculinity. It creates new standar of women's language.

However, it does not acquire in these two Mexican dramas as we call them as telenovelas. Mexico as part of America does not show the significant improvement in the perspective of language. These female characters are still describes as subaltern side toward men although in some aspects of the dramas they talks about swearing and taboo words. 


\section{REFERENCES}

$\mathrm{IMDb}$.

1994.

Marimar.

https://m.imdb.com/title/tt0130410/

Krismanti, Ninuk. (2020) Situating women in society: a study on traditional Mantras of

Banjar. JURNAL BASIS, [S.1.], v. 7, n. 1, p. 151-158, apr. 2020. ISSN 2527-8835.

Lakoff, Robin. (1975). Language and woman's place. Language and society, $2,45-79$

Martinez, Sonia Frais. (2007).

Measuring structureal gender equality in Mexico: s a state level analysis. Springer. DOI 10.1007/s1 1205-007-9193-4

Martinez, Sonia Frais. (2014). Gender Equality in Mexico. National Autonomous University of

Mexico, Regional Center for Multidisciplinary Research,

\section{Cuernavaca, Mexico}

Morales, Fernando \& Núria Simelio. (2016) Television and identities: analysis of the consumption of 'telenovelas' by the Latin American community in Spain, Identities, 23:5, 591609, DOI: 10.1080/1070289X.2015 .1042479

Nordquist, Richard. (2019). "Gender

(Sociolinguistics)." ThoughtCo, Jul. 3, 2019, thoughtco.com/gender-insociolinguistics-1690888.
Ronsini, Veneza Mayora. (2016).

Telenovela and the issue of classed femininity. MATRIZes. Volume 10 Number 2: p.46-60

Sandelowski M. (2010). What's in a name? Qualitative Description Revisited. Res Nurs Health. 33(1): 77-84

Sofia Rios. (2015). Representation and Disjunction: Made-up Maids in Mexican Telenovelas, Journal of Iberian and Latin American Research, 21:2, 223-

233, DOI: $10.1080 / 13260219.20$

15.1092647

Tiempo De Guerra. (2017). Episode 8 Season 1.

https://www.springfieldspringfie ld.co.uk/view_episode_scripts.php?tvshow=tiemppos- $\quad$ de-guerra2017\&episode $=\mathrm{s} 01 \mathrm{e} 08$

Tsika, Noah. (2019). Miracles from Mexico: Christianity, corporate restructuring, and the telenovela in Nigeria, Journal of African Cultural Studies, 31:2, 212225, DOI: $10.1080 / 13696815.20$ 18.1535961

Vis a Vis. (2015). Episode 1 Season 1. https://www.springfieldspringfie ld.co.uk/view_episode_scripts.php?tvshow $=$ vis- $\quad$ a-vis2015\&episode $=\mathrm{s} 01 \mathrm{e} 01$ 